\title{
FLEXURAL STRENGTH OF ACRYLIC RESINS POLYMERIZED BY DIFFERENT CYCLES
}

\author{
Débora Barros BARBOSA ${ }^{1}$, Raphael Freitas de SOUZA², Ana Carolina PERO ${ }^{3}$, Juliê MARRA ${ }^{3}$, Marco Antonio COMPAGNONI ${ }^{4}$
}

\author{
1- DDS, PhD, Assistant Professor, Department of Dental Materials and Prosthodontics, Dental School of Araçatuba, UNESP, Araçatuba, SP, \\ Brazil. \\ 2- DDS, PhD, Assistant Professor, Department of Dental Materials and Prosthodontics - Dental School of Ribeirão Preto, USP, Ribeirão Preto, \\ SP, Brazil. \\ 3- DDS, MSc, Graduate Student, Department of Dental Materials and Prosthodontics, Dental School of Araraquara,UNESP, Araraquara SP, \\ Brazil. \\ 4- DDS, PhD, Full Professor, Department of Dental Materials and Prosthodontics, Dental School of Araraquara, UNESP, Araraquara SP, Brazil. \\ Corresponding address: Dr. Marco Antonio Compagnoni - Rua Humaitá, 1680, Centro, 14801-903, Araraquara, SP, Brasil - Phone: 5516 \\ 3301-6411/ Fax: 5516 3301-6406 - e-mail: compagno@foar.unesp.br
}

Received: Octpber 31, 2006 - Modification: May 20, 2007 - Accepted: August 06, 2007

\begin{abstract}
D

espite the large number of studies addressing the effect of microwave polymerization on the properties of acrylic resin, this method has received limited clinical acceptance. This study evaluated the influence of microwave polymerization on the flexural strength of a denture base resin. A conventional heat-polymerized (Clássico), a microwave-polymerized (Onda-Cryl) and a autopolymerizing acrylic (Jet) resins were used. Five groups were established, according to polymerization cycles: A, B and $\mathrm{C}$ (Onda-Cryl, short cycle $-500 \mathrm{~W} / 3 \mathrm{~min}$, long $-90 \mathrm{~W} / 13 \mathrm{~min}+500 \mathrm{~W} / 90 \mathrm{sec}$, and manufacturing microwave cycle $-320 \mathrm{~W} /$ $3 \mathrm{~min}+0 \mathrm{~W} / 3 \mathrm{~min}+720 \mathrm{~W} / 3 \mathrm{~min})$; T $\left(\right.$ Clássico, water bath cycle $-74^{\circ} \mathrm{C} / 9 \mathrm{~h}$ ) and Q (Jet, press chamber cycle $-50^{\circ} \mathrm{C} / 15 \mathrm{~min}$ at 2 bar). Ten specimens $(65 \times 10 \times 3.3 \mathrm{~mm})$ were prepared for each cycle. The flexural strength of the five groups was measured using a three-point bending test at a cross-head speed of $5 \mathrm{~mm} / \mathrm{min}$. Flexural strength values were analyzed by one-way ANOVA and the Tukey's test was performed to identify the groups that were significantly different at $5 \%$ level. The microwave-polymerized groups showed the highest means $(p<0.05)$ for flexural strength $(\mathrm{MPa})(\mathrm{A}=106.97 \pm 5.31 ; \mathrm{B}=107.57 \pm 3.99 ; \mathrm{C}=109.63 \pm 5.19)$, and there were no significant differences among them. The heat-polymerized group $(\mathrm{T})$ showed the lowest flexural strength means $(84.40 \pm 1.68)$, and differ significantly from all groups. The specimens of a microwavable denture base resin could be polymerized by different microwave cycles without risk of decreasing the flexural strength.
\end{abstract}

Uniterms: Dentures; Acrylic resins; Microwaves; Physical properties; Strength.

\section{INTRODUCTION}

Poly(methyl methacrylate) (PMMA) is the most commonly used denture base resin, and its polymerization process may take place by different mechanisms ${ }^{8}$. Several processing methods have been proposed to simplify the technique and to reduce denture manufacturing time, in spite of the long acceptance of compression molding with the water-bath polymerization method. The convenience of using microwave energy in the food industry suggested similar advantages for denture processing. However, microwaved system have gained only limited clinical acceptance despite extensive laboratory research ${ }^{1,2,5,7,24}$.

In previous studies, most of the mechanical properties of denture base resins polymerized by microwave energy and conventional water-bath method were comparable ${ }^{2,17,19,21}$. Reitz, et al. ${ }^{17}$ (1985) and Shlosberg, et al. ${ }^{19}$ (1989) observed that the strength of the denture base resin polymerized by microwave was not significantly different by microwave-polymerized denture base resin. Alkhatib, et al. ${ }^{2}$ (1990) compared two microwave and one water bathpolymerized resins. No significant differences in flexural strengths were found regardless of the polymerization method. Other works ${ }^{3,21}$ showed higher flexural strength for microwave-processed acrylic resins.

Some authors ${ }^{11,12,14}$ have reported that high levels of residual monomer have a deleterious effect on the mechanical properties of denture base polymers. Also, the level of residual monomer and the mechanical properties are closely related to the polymerization conditions ${ }^{10}$. Harrison and Huggett ${ }^{12}$ (1992) evaluated the effect of the polymerization cycle on residual monomer levels of denture base resins, and concluded that when terminal boils was used, the levels of residual monomer were markedly decreased. These authors also cited that the rate of heat application and the thickness of the denture base polymers are influencing factors. Furthermore, these investigations have indicated that in addition to obtaining minimal levels 
of unpolymerized monomer, denture base resins must be porosity free and therefore an appropriate polymerization cycle is essential to prevent high exothermic reactions.

The greater advantage of microwave heating over conventional heat is that temperature rises fast. However, the important factor for consideration is the careful control of the temperature during polymerization processing. De Clerck $^{9}(1987)$ reported that microwaves do not automatically heat the monomer to the correct temperature of $100.8^{\circ} \mathrm{C}$, which can be easily surpassed during polymerization using microwave energy. Therefore, this temperature must be monitored and controlled accurately, and the timing must be correct ${ }^{9}$. This author observed external porosity when the acrylic resin specimens have absorbed too much energy in the beginning of the polymerization, and internal porosity when too much energy was applied at the end of polymerization using microwave energy. Reitz, et al. ${ }^{17}$ (1985) and Alkhatib, et al. ${ }^{2}$ (1990) also noted that the porosity in thick specimens polymerized by microwave energy could be reduced by a longer polymerization time at a lower wattage.

Lai, et al. ${ }^{15}$ (2004) established the time and temperature required for the complete conversion of monomer to polymer, and compared physical and mechanical properties of microwave- and water bath-polymerized acrylic resin specimens. The specimens were polymerized at different times and wattages. The higher power applied to the system, the more the resin temperatures rises, the faster the benzoyl peroxide decomposes, and more rapid is the polymerization reaction. The flexural strength of the specimens polymerized by microwave energy showed strength of $89-92 \%$ of water bath polymerized ones. They concluded that microwave energy can effectively polymerize denture base polymer, and has a potential for saving time in processing dentures. However, it has been stated that the choice of a suitable power and polymerization time is important in order to reduce porosity to a minimum level.

The aim of this study was to compare the flexural strength of a denture base resin polymerized by various microwave cycles to a conventional heat-polymerized and a autopolymerizing acrylic resin, based on the hypothesis that microwave-polymerized denture base resins exhibit flexural strength in the same range as other resins.

\section{MATERIAL AND METHODS}

Five protocols (cycles) were used to polymerize the acrylic resins (Table 1). Clear acrylic resins were chosen in order to identify more easily whether specimens were free of porosity. Cycles A and B were based on works published elsewhere ${ }^{4,5,7,18,23}$. It has been shown that using a longer cycle at a lower-wattage may decrease porosity significantly 18,23 .

The denture resin specimens to flexural strength analysis were prepared by partially investing metal patterns in the conventional metal flasks for cycles $\mathrm{T}$ and $\mathrm{Q}$ and in the

TABLE 1- Acrylic resins and polymerization cycles used in this study

\begin{tabular}{|c|c|c|c|}
\hline Material & Lot number & Manufacturer & Polymerization cycle \\
\hline $\begin{array}{c}\text { Onda-Cryl (clear } \\
\text { microwave-polymerized } \\
\text { acrylic resin) }\end{array}$ & 404050 & $\begin{array}{c}\text { Artigos Odontológicos } \\
\text { Clássico Ltd, São Paulo, SP, } \\
\text { Brazil }\end{array}$ & $\begin{array}{l}\text { A: Microwave oven: } 500 \mathrm{~W} \text { for } 3 \\
\min \end{array}$ \\
\hline Onda-Cryl & 404050 & $\begin{array}{l}\text { Artigos Odontológicos } \\
\text { Clássico Ltd }\end{array}$ & $\begin{array}{l}\text { B: Microwave oven: } 90 \mathrm{~W} \text { for } 13 \\
\min +500 \mathrm{~W} \text { for } 90 \mathrm{sec}\end{array}$ \\
\hline Onda-Cryl & 404050 & $\begin{array}{l}\text { Artigos Odontológicos } \\
\text { Clássico Ltd }\end{array}$ & $\begin{array}{c}\text { C: Microwave oven: } 320 \mathrm{~W} \text { for } 3 \\
\min +0 \mathrm{~W} \text { for } 4 \min +720 \mathrm{~W} \text { for } 3 \\
\min { }^{*}\end{array}$ \\
\hline $\begin{array}{c}\text { Clássico (clear } \\
\text { conventional heat- } \\
\text { polymerized acrylic resin) }\end{array}$ & 404050 & $\begin{array}{l}\text { Artigos Odontológicos } \\
\text { Clássico Ltd }\end{array}$ & $\begin{array}{c}\text { T: Conventional water bath: } 74^{\circ} \mathrm{C} \\
\text { for } 9 \mathrm{~h}\end{array}$ \\
\hline $\begin{array}{c}\text { Jet (clear } \\
\text { autopolymerizing acrylic } \\
\text { resin) }\end{array}$ & 404050 & $\begin{array}{l}\text { Artigos Odontológicos } \\
\text { Clássico Ltd }\end{array}$ & $\begin{array}{l}\text { Q: Press chamber: } 50^{\circ} \mathrm{C} \text { for } 15 \\
\text { min at } 2 \text { bar }\end{array}$ \\
\hline
\end{tabular}

* Cycle recommended by Onda-Cryl manufacturer. 
fiber-glass-reinforced plastic flasks for microwave polymerization cycles (A, B and C). To facilitate removal from the flask, the master patterns were individually invested in high-viscosity silicone (Zetalabor, Zhermack S.p.A., Badia Polesine, Rovigo, Italy) and were then further supported by dental stone (Herodent, Vigodent S/A Ind. Com., Rio de Janeiro, RJ, Brazil) within the flasks. After the invested material had set, the flasks were separated, and the master pattern was removed from the silicone mold. Each acrylic resin was mixed according to the manufacturer's recommendations. The resin was then packed and polymerized according to the cycles listed in Table 1.T and Q specimens were processed, respectively, in an automatic polymerization tank (Termotron P-100, Termotron Equipamentos, Piracicaba, SP, Brazil) and in a press chamber (Termo Press, Promeco Ind Eletro Mecânica Ltd, São Paulo, SP, Brazil). For the microwave polymerization method, a domestic microwave oven with a rotating table was used (Continental AW-30, Bosh Eletrodomésticos, Manaus, AM, Brazil).

Ten specimens from each cycle were prepared by investing metal patterns with dimensions of $67 \times 12 \times 5.3 \mathrm{~mm}$. After processing, the resin specimens were polished in a polishing machine (Metaserv 2000, Buehler, UK Ltd., Coventry, England) to a final dimension of $65 \times 10 \times 3.3 \mathrm{~mm}$, according to the International Organization for Standardization (ISO/FDIS 1567) ${ }^{13}$. All surfaces of the specimens were finished with 280 and 320-grit wet-dry sandpaper (Norton, Saint-Gobain Abrasivos Ltda, Vinhedo, SP, Brazil) followed by 400 and 600-grit sandpaper. A micrometer was used to record precise specimen measurements. All specimens were stored in distilled water at $37^{\circ} \mathrm{C}$ for $50 \pm 2$ hours before testing ${ }^{13}$.

The flexural strength of the five cycle groups were measured using a three-point bending test in a material test system machine (Model 810, MTS System Corp, Edden Praire, Minnesota, USA) at a crosshead speed of $5 \mathrm{~mm} / \mathrm{min}$. The flexural strength (TS) was calculated using the formula: $T S=3 W L / 2 b d 2$, where $W$ is the maximum load before fracture, $L$ is the distance between supports $(50 \mathrm{~mm}), b$ is the specimen width and $d$ is the specimen thickness.

Statistical analyses were completed using a one-way analysis of variance (ANOVA) and Tukey's test for posthoc comparisons. All analyses were performed at a $95 \%$ level of confidence. Data were analyzed with SPSS for Windows software (version 12.0.0, Chicago, IL, USA).

\section{RESULTS}

Flexural strength means and standard deviation for the cycles are listed in Table 2. There was a significant difference between the three polymerization methods (microwave, conventional water bath and autopolymerizing method), with cycle T exhibiting the lowest value (Table 2). Tukey's test showed a significantly higher flexural strength for microwave-polymerized denture resin, regardless of the polymerization cycle, and there were no differences among any of these groups.

\section{DISCUSSION}

Flexural failure of denture base resins is considered the primary mode of clinical failure ${ }^{6}$. The flexural three-point bending test is useful in comparing denture base materials as it simulates the type of stress that is applied to the denture during mastication ${ }^{25}$.

This study compared the flexural strength of a microwavepolymerized denture base resin (Onda-Cryl) with a conventional heat-polymerized (Clássico) and an autopolymerizing acrylic resin (Jet). Based on the results, the hypothesis that microwave-polymerized denture resin specimens exhibit flexural strength in the same range as that of heat- and autopolymerizing resins was not accepted. The results showed higher flexural strength for Onda-Cryl, regardless of the polymerization cycle. Clássico denture base resin demonstrated the lowest value of flexural strength (84.4 $\mathrm{MPa}$ ), indicating its inferior strength and low resistance to fracture. These findings are consistent with previous studies $^{2,3,21}$ that found a statistically higher flexural strength for microwave-processed denture resins. In spite of these results, the flexural strength values for the heat-polymerized resin were in accordance with those found by other authors ${ }^{2}$. For both autopolymerizing and heat-polymerized acrylic resins, the level of residual monomer in the resin and the mechanical properties are closely related to the polymerization conditions ${ }^{11,12,14}$.

According to Harrison and Huggett ${ }^{12}$ (1992) the long water bath cycles without terminal boil show levels of residual monomer approximately 3 times greater than when a terminal boil is used. The residual monomer could affect the flexural strength because of a plasticizing effect, which effectively reduces interchange forces ${ }^{14}$. Consequently, deformation would occur more easily under load. The terminal boil was

TABLE 2- Means and standard deviations for flexural strength tests (MPa)

\section{Cycle}

\begin{tabular}{ccccc}
\hline A & B & C & T & Q \\
$106.97 \mathrm{a}( \pm 5.31)$ & $107.57 \mathrm{a}( \pm 3.99)$ & $109.63 \mathrm{a}( \pm 5.19)$ & $84.40 \mathrm{~b}( \pm 1.68)$ & $92.84 \mathrm{c}( \pm 4.73)$ \\
\hline
\end{tabular}

*Different letters indicate statistically significant difference at $5 \%$. 
not used in the water bath cycle (T). It could explain the results found with heat-polymerized denture base resin.

The heat-polymerized specimens also showed the lowest strength values, even though autopolymerizing resin. The resin specimens of that have been polymerized for a long period in water may absorb water continuously ${ }^{20}$, and it could act as a plasticizer, reducing the glass transition temperature $(\mathrm{Tg})$ and the evaluated mechanical property. It might have happened with Clássico denture base resin. The autopolymerizing acrylic resin was polymerized under pressure and at $50^{\circ} \mathrm{C}$. It could have improved the fracture strength of Jet acrylic resin. Vallittu, et al. ${ }^{22}$ (1998) demonstrated that the increase of the polymerization temperature for autopolymerizing resins from $30^{\circ} \mathrm{C}$ to $60^{\circ} \mathrm{C}$, decreased the residual monomer content of the polymer from an average of $4.6 \mathrm{wt} \%$ to $3.3 \mathrm{wt} \%$. Ogawa, et al. ${ }^{16}$ (2000) found that the transverse strength of autopolymerizing resin increased with an increase in water temperature, and concluded the polymerization of the autopolymerizing resin in hot water greatly improves its mechanical properties. Heat may have activated the chemical reaction between the monomer and polymer components of the resin and produces more complete polymerization. This mechanism may explain why hot water conditions improved the mechanical properties of the autopolymerizing acrylic resin.

This study has also shown that microwave energy can efficiently polymerize denture base polymer. The results of flexural strength indicated that the evaluated microwavepolymerized resin can be polymerized by cycles A, B and C without strength impairment. Even though there were no significant differences among microwave cycles, cycle A produced the lowest flexural strength values. The specimens polymerized on that cycle absorbed more energy in the beginning of the reaction, and then there was a rapid rise in the resin temperature ${ }^{9,15}$. It could lead to the formation of porosities, and decreased the flexural strength values.

Lai, et al. ${ }^{15}$ (2004) demonstrated the effectiveness of denture base resin polymerization by microwave energy. They suggested 7, 10, and 15 min to polymerize acrylic resins at 240,160 and $80 \mathrm{~W}$, respectively. Then, the flask should be turned over, and polymerized for additional 2 minutes at 560 $\mathrm{W}$ to complete polymerization. In the same way of the present study, they did not find any significant difference among specimens polymerized by any of the microwave cycles. Although it had been observed, they found that the acrylic resin blocks polymerized at $240 \mathrm{~W}$ seemed to be superior to other microwave-polymerized blocks because of their little porosity and sufficiently polymerized state.

This study involved a limited analysis of a mechanical property for only one denture base resin polymerized by microwave energy. Further research should be conducted to compare different microwave ovens, other denture base resins, and how they could affect other physical and mechanical properties of these materials. To overcome the limitations of in vitro tests, denture base resins should be evaluated intraorally.

The clinical implication of this study is that the polymerization of denture base resin using microwave energy may have a positive effect on the strength and longevity of complete dentures. Also, microwave energy has a potential for saving a great amount of time in processing dentures.

\section{CONCLUSIONS}

Within the limitations of this in vitro study, the results suggested that the microwave-processed specimens showed a significantly higher flexural strength than the other ones. The flexural strength means for the specimens polymerized by conventional water bath $(\mathrm{T})$ were comparable to those of the autopolymerizing resin specimens $(\mathrm{Q})$. The microwave-cycles (A, B and C) can be used without compromising damages to the acrylic resin strength. However, it has been stated that the choice for a suitable power and polymerization time is important in order to reduce porosity to a minimum level.

\section{ACKNOWLEDGMENTS}

The authors thank Pieter François du Plessis for an English review of the text, and FAPESP(01/06720-8), CAPES and $\mathrm{CNPq}$ for financial support.

\section{REFERENCES}

1- Al Doori D, Huggett R, Bates JF, Brooks SC. A comparison of denture base acrylic resins polymerised by microwave irradiation and by conventional water bath curing systems. Dent Mater. 1988;4:2532 .

2- Alkhatib MB, Goodacre CJ, Swartz ML, Munoz-Viveros CA, Andres CJ. Comparison of microwave-polymerized denture base resins. Int J Prosthodont. 1990;3:249-55.

3- Archadian N, Kawano F, Ohguri T, Ichikawa T, Matsumoto N. Flexural strength of rebased denture polymers. J Oral Rehabil. 2000;27:690-6.

4- Bafile M, Graser GN, Myers ML, Li EK. Porosity in denture resin cured by microwave energy. J Prosthet Dent. 1991;66:269-74.

5- Barbosa DB, Compagnoni MA, Leles CR. Changes in occlusal vertical dimension in microwave processing of complete dentures. Braz Dent J. 2002;13:197-200.

6- Chitchumnong P, Brooks SC, Stafford GD. Comparison of threeand four-point flexural strength testing of denture base polymers. Dent Mater. 1989;51:2-5.

7- Compagnoni MA, Barbosa DB, Souza RF, Pero AC. The effect of polymerization cycles on porosity in microwave-processed denture base resin. J Prosthet Dent. 2004;91:281-5.

8- Craig RG, Powers JM. Restorative dental materials. St Louis: CV Mosby; 2002. p:20-35, p.635-89.

9- De Clerck JP. Microwave polymerization of acrylic resins used in dental prostheses. J Prosthet Dent. 1987;57:650-8. 
10 - Dogan A, Bek B, Cevik NN, Usanmaz A. The effect of preparation conditions of acrylic denture base materials on the level of residual monomer, mechanical properties and water absorption. J Dent. $1995 ; 23: 313-8$

11-Grajower R, Goultschin J. The transverse strength of acrylic resin strips and of repaired acrylic samples. J Oral Rehabil. $1984 ; 11: 237-47$.

12- Harrison A, Huggett R. Effect of the curing cycle on residual monomer levels of acrylic resin denture base polymers. J Dent. $1992 ; 20: 370-4$

13-International Organization for Standardization, 1998; Specification 1567: denture base polymers. 2nd ed. Geneva: ISO; 1998.

14- Jagger RG. Effect of the curing cycle on some properties of a polymethylmethacrylate denture base material. J Oral Rehabil. 1978;5:51-7.

15- Lai CP, Tsai MH, Chen M, Chang HS, Tay HH. Morphology and properties of denture acrylic resins cured by microwave energy and conventional water bath. Dent Mater. 2004;20:133-41.

16- Ogawa T, Tanaka M, Koyano K. Effect of water temperature during polymerization on strength of autopolymerizing resin. J Prosthet Dent. 2000;84:220-4

17- Reitz PV, Sanders JL, Levin B. The curing of denture acrylic resins by microwave energy. Physical properties. Quintessence Int $1985 ; 16: 547-51$.

18 - Sanders JL, Levin B, Reitz PV. Porosity in denture acrylic resins cured by microwave energy. Quintessence Int. 1987;18:453-6.

19- Shlosberg SR, Goodacre CJ, Munoz CA, Moore BK, Schnell RJ. Microwave energy polymerization of poly(methyl methacrylate) denture base resin. Int J Prosthodont. 1989;2:453-8.

20 - Smith LSA, Schmitz V. The effect of water sorption on the glass transition temperature of poly(methyl methacrylate). Polymer. 1988;29:1871-8.

21 - Smith LT, Powers JM, Ladd D. Mechanical properties of new denture resins polymerized by visible light, heat, and microwave energy. Int J Prosthodont. 1992;5:315-20.

22- Vallittu PK, Ruyter IE, Buykuilmaz S. Effect of polymerization temperature and time on the residual monomer content of denture base polymers. Eur J Oral Sci. 1998;106:588-93.

23 - Yannikakis S, Zissis A, Polyzois G, Andreopoulos A. Evaluation of porosity in microwave-processed acrylic resin using a photographic method. J Prosthet Dent. 2002;87:613-9.

24- Yunus N, Harrison A, Huggett R. Effect of microwave irradiation on the flexural strength and residual monomer levels of an acrylic resin repair material. J Oral Rehabil. 1994;21:641-8.

25 - Yunus N, Rashid AA, Azmi LL, Abu-Hassan MI. Some flexural properties of a nylon denture base polymer. J Oral Rehabil. 2005;32:65-71. 